\title{
Sulfidogenesis under extremely haloalkaline conditions by Desulfonatronospira thiodismutans gen. nov., sp. nov., and Desulfonatronospira delicata sp. nov. - a novel lineage of Deltaproteobacteria from hypersaline soda lakes
}

\begin{abstract}
Correspondence
Dimitry Yu. Sorokin

soroc@inmi.host.ru;

D.Y.Sorokin@tudelft.nl
\end{abstract}

Received 5 December 2007

Revised 29 January 2008

Accepted 23 February 2008
Dimitry Yu. Sorokin, ${ }^{1,2}$ Tatjana P. Tourova, ${ }^{1}$ Anne M. Henstra, ${ }^{3}$ Alfons J. M. Stams, ${ }^{3}$ Erwin A. Galinski ${ }^{4}$ and Gerard Muyzer ${ }^{2}$

${ }^{1}$ Winogradsky Institute of Microbiology, Russian Academy of Sciences, Prospect 60-let Octyabrya 7/2, 117811 Moscow, Russia

${ }^{2}$ Environmental Biotechnology, Department of Biotechnology, Delft University of Technology, Delft, The Netherlands

${ }^{3}$ Laboratory of Microbiology, Wageningen University, Wageningen, The Netherlands

${ }^{4}$ Institute of Microbiology and Biotechnology, Rheinische Friedrich-Wilhelms University, Bonn, Germany

High rates of sulfidogenesis were observed in sediments from hypersaline soda lakes. Anaerobic enrichment cultures at $2 \mathrm{M} \mathrm{Na}^{+}$and $\mathrm{pH} 10$ inoculated with sediment samples from these lakes produced sulfide most actively with sulfite and thiosulfate as electron acceptors, and resulted in the isolation of three pure cultures of extremely natronophilic sulfidogenic bacteria. Strain ASO3-1 was isolated using sulfite as a sole substrate, strain AHT 8 with thiosulfate and formate, and strain AHT 6 with thiosulfate and acetate. All strains grew in a mineral soda-based medium by dismutation of either sulfite or thiosulfate, as well as with sulfite, thiosulfate and sulfate as acceptors, and $\mathrm{H}_{2}$ and simple organic compounds as electron donors. The acetyl-CoA pathway was identified as the pathway for inorganic carbon assimilation by strain ASO3-1. All strains were obligately alkaliphilic, with an optimum at $\mathrm{pH} 9.5-10$, and grew in soda brines containing 1-4 $\mathrm{M}$ total $\mathrm{Na}^{+}$(optimum at 1.0-2.0 M). The cells accumulated high amounts of the organic osmolyte glycine betaine. They formed a new lineage within the family Desulfohalobiaceae (Deltaproteobacteria), for which the name Desulfonatronospira gen. nov. is proposed. Strains ASO3 $-1^{\top}$ and AHT 8 from Kulunda Steppe formed Desulfonatronospira thiodismutans sp. nov., and strain AHT $6^{\top}$ from Wadi al Natrun is suggested as Desulfonatronospira delicata sp. nov.

\section{INTRODUCTION}

Soda lakes are extreme habitats with a stable high $\mathrm{pH}$ due to a high carbonate alkalinity and a varying salt content, up to saturation. The sulfur cycle appears to be the most active element cycle in soda lakes. High primary productivity,

Abbreviations: CFE, cell-free extract; SRB, sulfate-reducing bacteria; TCA cycle, tricarboxylic acid cycle.

The GenBank/EMBL/DDBJ accession numbers for the 16S rRNA gene sequences of strains ASO3- $1^{\top}$, AHT $6^{\top}$ and AHT 8 are EU296537EU296539.

A supplementary table showing a comparison of cellular fatty acid profiles of extremely natronophilic sulfidogenic isolates from hypersaline soda lakes with low salt-tolerant alkaliphilic and high salt-tolerant halophilic members of the family Desulfohalobiaceae is available with the online version of this paper. high sulfate concentrations (Ryu et al., 2004) and high energy yields of sulfur-dependent dissimilatory metabolism (Oren, 1999) could be the reasons for this phenomenon. Our investigation of the oxidative part of the sulfur cycle in soda lakes has resulted in the isolation and characterization of more than a hundred strains of chemolithoautotrophic sulfur-oxidizing gammaproteobacteria that are well adapted to extreme haloalkaline conditions (Sorokin \& Kuenen, 2005; Sorokin et al., 2006). However, little is known about the reductive part of the sulfur cycle in soda lakes. So far, only two culturable groups of moderately salttolerant alkaliphilic sulfate-reducing bacteria (SRB) belonging to the Deltaproteobacteria (order Desulfovibrionales) have been found in soda lakes. The genus Desulfonatronovibrio includes a single species, while the genus Desulfonatronum contains three species. Both utilize 
acetate as a carbon source, but not as an electron donor. $\mathrm{H}_{2}$ is used as an electron donor, but autotrophy has been reported only for Desulfonatronum thiodismutans (Zhilina et al., 1997, 2005; Pikuta et al., 1998, 2003). Quantitative data on SRB activity in soda lakes are scarce. The data on stratified alkaline lakes from North America indicate a sharp decrease of activity at a salt content above $100 \mathrm{~g} \mathrm{l}^{-1}$ (Kulp et al., 2006), while our data on shallow soda lakes from Central Asia demonstrate high rates of sulfate reduction under hypersaline conditions up to saturation (Sorokin et al., 2004; Foti et al., 2007, 2008). The latter data suggest the presence of an active, but yet uncultured, high salt-tolerant alkaliphilic SRB group(s) in hypersaline soda lakes. Such SRB are presently known only among neutrophilic representatives of the family Desulfohalobiaceae, including the genera Desulfohalobium (Ollivier et al., 1991) and Desulfovermiculus (Belyakova et al., 2006). Culture-independent studies of the SRB populations in soda lakes so far are limited to two studies. In Mono Lake in California, $16 \mathrm{~S}$ rDNA targeting has successfully identified representatives of several groups of deltaproteobacterial SRB (Scholten et al., 2005). Similar studies with sediments from soda lakes of the Kulunda Steppe (Altai, Russia) targeting the $\operatorname{ds} r A B$ gene (encoding the key enzyme dissimilatory sulfite reductase) have demonstrated the presence of two major groups of deltaproteobacterial SRB: one in Desulfovibrionales, related to two culturable groups; and several lineages within the family Desulfobacteriaceae, which includes mostly species utilizing acetate as electron donor (Foti et al., 2007). This suggests the presence of important functional, but yet uncultured, groups of bacteria involved in the reductive part of the sulfur cycle in soda lakes.

In the current paper we describe a novel group of obligately alkaliphilic SRB found in hypersaline soda lakes. The most striking feature of these SRB was the potential to grow chemolithoautotrophically by fermentation (dismutation) of sulfite and thiosulfate. They represent a novel genus within the family Desulfohalobiaceae, for which we propose the name Desulfonatronospira gen. nov.

\section{METHODS}

Samples and sulfidogenesis activity in lake sediments. Two sets of combined sediment samples, from Kulunda Steppe (Altai, Russia; 10 subsamples taken in 2005-2006) and from Wadi al Natrun (Egypt, eight subsamples taken in 2000) soda lakes, were used as an inoculum to enrich for high salt-tolerant alkaliphilic SRB. The lake properties have been described previously (Sorokin \& Kuenen, 2005; Foti et al., 2007, 2008). Potential rates of sulfidogenesis from sulfate and thiosulfate at high-salt conditions were measured with a sample from the hypersaline soda lake Bitter-1 at the Kulunda Steppe (July 2007) in a sediment slurry experiment (water $\mathrm{pH}=10.53$, alkalinity $=2.95 \mathrm{M}$; total salt $=18.2 \%$; sulfate $=9.8 \mathrm{mM}$; free sulfide in the sediments $=0.95-1.30 \mathrm{mM}$ ). For this, one part of sediment from the top $10 \mathrm{~cm}$ layer was mixed with two parts of the near-bottom water sediment, and incubated anaerobically in duplicate with various electron donors and acceptors at $28{ }^{\circ} \mathrm{C}$. Samples $(100 \mu \mathrm{l})$ were taken regularly with a syringe for sulfide analysis. The maximum rates of sulfidogenesis were calculated for the linear period of sulfide production.
Medium composition and growth experiments. A mineral medium based on sodium carbonate buffer at $\mathrm{pH} 10$ containing $2.3 \mathrm{M}$ total $\mathrm{Na}^{+}$was used for the enrichments (concentrations in $\mathrm{g}$ $\left.1^{-1}\right): \mathrm{Na}_{2} \mathrm{CO}_{3}, 95 ; \mathrm{NaHCO}_{3}, 15 ; \mathrm{NaCl}, 15 ; \mathrm{K}_{2} \mathrm{HPO}_{4}, 0.5$. For pure culture studies, the soda content of the mineral base varied from 0.6 to $4 \mathrm{M}$ total $\mathrm{Na}^{+}$. After sterilization, the medium was supplemented with $1 \mathrm{mM} \mathrm{MgCl} 2,1 \mathrm{ml} \mathrm{l}^{-1}$ trace metal solution (Pfennig \& Lippert, 1966) and $0.1 \mathrm{mg} \mathrm{l}^{-1}$ filter-sterilized vitamin $B_{12}$. Sulfite was used at a final concentration of $10 \mathrm{mM}$, thiosulfate and sulfate at a concentration of $20 \mathrm{mM}$. Other electron acceptors were used at $5 \mathrm{mM}$ concentration. Electron donors were used at $10 \mathrm{mM}$ concentration, except formate, which was used at a concentration of $50 \mathrm{mM}$. Routine cultivation was performed in $100 \mathrm{ml}$ serum bottles that were closed with butyl rubber stoppers and contained $80 \mathrm{ml}$ of culture medium. In the case of $\mathrm{H}_{2}$ as electron donor, the amount of medium was reduced to $50 \mathrm{ml}$. After the addition of the electron donor and electron acceptor, the cultures were made anoxic by several cycles of evacuation-flushing with argon or hydrogen. Sodium sulfide ( $1 \mathrm{mM})$ was used as a reducing agent. The cultures were incubated at $30{ }^{\circ} \mathrm{C}$ and were periodically checked for sulfide production. When the sulfide concentration exceeded 5-8 $\mathrm{mM}$, the culture was transferred into new medium at a $1: 100$ dilution. After two to three successful transfers, the enrichments were serially diluted up to $10^{-11}$ using Hungate tubes with $10 \mathrm{ml}$ medium. The latter was repeated several times until final purification of the dominant sulfidogenic bacteria was achieved, since none of them formed colonies in alkaline agar shake tubes. Culture purity was checked by microscopy and by sequencing of the $16 \mathrm{~S}$ rRNA genes. The $\mathrm{pH}$ dependence of growth was examined at an $\mathrm{Na}^{+}$content of $2 \mathrm{M}$, using the following filtersterilized mineral media: for $\mathrm{pH}$ 6-8, 0.1 M HEPES and $\mathrm{NaCl}$; for $\mathrm{pH}$ 8-11, a mixture of sodium bicarbonate/sodium carbonate containing $0.1 \mathrm{M} \mathrm{NaCl}$. Growth resulted in a shift of the initial $\mathrm{pH}$ values, especially in the highly alkaline region. Therefore, final $\mathrm{pH}$ values were taken to indicate a suitable range for growth. To study the influence of salt concentration on growth, mineral media containing 0.1 and $4.0 \mathrm{M}$ total $\mathrm{Na}^{+}$at $\mathrm{pH} 10$ were mixed in different proportions. The fate of acetate in pure cultures was investigated using cells from the late-exponential phase incubated with uniformly labelled $\left[{ }^{14} \mathrm{C}\right]$ acetic acid at 100000 d.p.m. ml ${ }^{-1}$ final radioactivity. After $6 \mathrm{~h}$ of incubation, the supernatant was acidified and $\mathrm{CO}_{2}$ was captured in phenethylamine scintillator liquid. The distribution of ${ }^{14} \mathrm{C}$ between assimilation into biomass and assimilation into inorganic carbon was then estimated.

Enzyme activity. The activity of key enzymes of the reductive acetylCoA pathway, the reductive tricarboxylic acid cycle (TCA cycle), and hydrogenase in cell-free extract (CFE) of strain ASO3-1 was analysed spectrophotometrically at $30{ }^{\circ} \mathrm{C}$, following the methods of Zeikus et al. (1977) and Schauder et al. (1987). CFE was obtained after sonication of the cell pellet in Tris buffer and subsequent centrifugation $(16000 \mathrm{~g}, 20 \mathrm{~min}$, room temperature).

Analytical procedures. Sulfide was precipitated in $10 \%(\mathrm{w} / \mathrm{v}) \mathrm{Zn}$ acetate, and subsequently analysed by the methylene blue method after separation from the supernatant (Trüper \& Schlegel, 1964). Thiosulfate and sulfite were determined by iodimetry of the supernatant after separation of $\mathrm{ZnS}$ by centrifugation. First, the sum of sulfite and thiosulfate was measured, and then thiosulfate alone after the removal of sulfite with formaldehyde $(3.7 \%$, v/v, final concentration). Cell protein was measured by the Lowry method after removal of interfering sulfur compounds. Several washing steps with $2 \mathrm{M} \mathrm{NaCl}$ acidified to $\mathrm{pH} 4$ were necessary to remove FeS from the cell pellets. Membrane fatty acids were extracted from the freeze-dried cells with methanol/chloroform and analysed by GC-MS, as described by Zhilina et al. (1997). Organic-compatible solutes were extracted from the lyophilized cells by ethanol and analysed by HPLC (Galinski \& Herzog, 1990). Phase-contrast photomicrographs were obtained 
with a Zeiss Axioplan Imaging 2 microscope. For electron microscopy of total cells, the cells were resuspended in $2 \mathrm{M} \mathrm{NaCl}$, fixed with glutaraldehyde $(3 \%, \mathrm{v} / \mathrm{v}$, final concentration) and positively contrasted with $1 \%(\mathrm{w} / \mathrm{v})$ uranyl acetate.

Genetic and phylogenetic analysis. The isolation of the DNA and determination of the $\mathrm{G}+\mathrm{C}$ content of the DNA were performed according to Marmur (1961) and Marmur \& Doty (1962), respectively. For DNA-DNA hybridization, a thermal denaturation technique was employed (De Ley et al., 1970). For PCR, genomic DNA was extracted from the cells using the UltraClean Soil DNA Extraction kit (MolBio Laboratories), following the manufacturer's instructions. The nearly complete $16 \mathrm{~S}$ rRNA gene was obtained from pure cultures using bacterial primers GM3F and GM4R. The PCR products were purified from low-melting agarose using the Wizard PCR-Prep kit (Promega). Sequencing was performed using the BigDye Terminator v3.1 Sequencing kit and an ABI 3730 automatic DNA sequencer (Applied Biosystems). The 16S rRNA sequences were first compared to sequences stored in the GenBank database using the BLAST search tool. The sequences were aligned with those from GenBank using CLUSTAL w. Phylogenetic trees were reconstructed with four different algorithms using the TREECONW software package (van de Peer \& De Wachter, 1994). Pairwise evolutionary distances (expressed as estimated changes per 100 nucleotides) were computed by using the Jukes and Cantor method. The resulting phylogenetic tree was constructed by the neighbour-joining method. Bootstrap analysis (1000 replications) was used to validate the reproducibility of the branching patterns of the trees.

\section{RESULTS}

\section{Sulfidogenesis activity of hypersaline soda lake sediments}

Our previous work with $\left[{ }^{35} \mathrm{~S}\right]$ sulfate had shown relatively high rates of in situ sulfate reduction $\left(4-50 \mu \mathrm{mol} \mathrm{dm}^{-3} \mathrm{~h}^{-1}\right)$ in the sediments from hypersaline soda lakes in north-east Mongolia (lakes Hotontyn and Shar-Burdiin) (Sorokin et al., 2004) and in Kulunda Steppe, Altai, Russia (lakes Tanatar-1, Picturesque, Bitter-1) (Foti et al., 2007, 2008). To get more information on the process, potential sulfidogenesis was measured in the sediment slurries obtained in July 2007 in lake Bitter-1 using sulfate and thiosulfate as electron acceptors and various electron donors. The results (Fig. 1) demonstrated the presence of a highly active sulfidogenic population at in situ salt-pH conditions. The rate of endogenous sulfate reduction (without external electron donors) was comparable with that obtained previously by the radiotracer technique. However, thiosulfate, but not sulfate, was the favoured electron acceptor. The potential rate of endogenous sulfidogenesis with thiosulfate was four times higher than with sulfate, while in the presence of external electron donors it became seven times higher. Another interesting conclusion from this experiment was that $\mathrm{H}_{2}$ and lactate, usually considered as the best electron donors for sulfate reduction, were much less efficient than formate and glucose (the latter probably indirectly through fermentation products), especially in the case of thiosulfate reduction.

\section{Enrichment and isolation of pure cultures}

To enrich for high salt-tolerant alkaliphilic sulfidogens, several enrichment cultures at $2 \mathrm{M} \mathrm{Na}^{+}, \mathrm{pH} 10$, were incubated with different combinations of electron donor/ acceptor using two sediment mixtures composed of the samples from hypersaline lakes in Kulunda Steppe and Wadi al Natrun. Stable sulfide-positive cultures were obtained only with thiosulfate and sulfite, but not with sulfate as electron donor, using formate, lactate, ethanol or $\mathrm{H}_{2}$ as electron donor. With sulfate, sulfidogens were eventually outcompeted by acetogenic clostridia. From sulfite/thiosulfate enrichments, only three cultures showed stable growth and sulfidogenesis in further transfers: a culture on sulfite as the only substrate from Kulunda Steppe; a culture on formate plus thiosulfate from Kulunda Steppe; and a culture on acetate plus thiosulfate from Wadi al Natrun. Since in agar shake tubes only mixed colony formation was achieved, several sets of serial dilutions were necessary to purify the dominant sulfidogenic bacteria from the enrichments mentioned above. Three pure cultures were eventually obtained. Strain ASO3-1 originated from the sulfite-only culture, strain AHT 8 from the

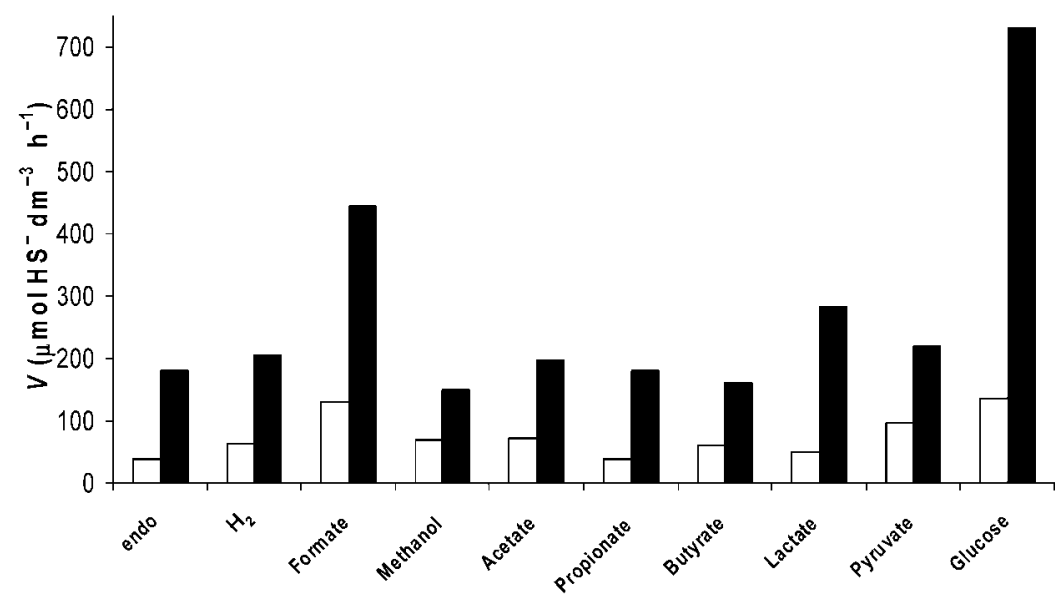

Fig. 1. Potential rates of sulfidogenesis with sulfate (open bars) and thiosulfate (closed bars) in sediment slurries from hypersaline soda Bitter-1 Lake (Kulunda Steppe, Altai, Russia). Sulfate was present at the native concentration of $6 \mathrm{mM}$ and thiosulfate was added at up to $2 \mathrm{mM}$. Electron donors were added at $2 \mathrm{mM}$ concentrations. endo, no addition of external electron donor. 
formate plus thiosulfate culture, and strain AHT 6 from the acetate plus thiosulfate culture.

\section{Cell morphology}

All three pure cultures had vibrio-shaped cells of variable size with a single polar flagellum. Cells of ASO3-1 and AHT 8 were considerably larger than those of AHT 6, and became long spirilla in the presence of an organic electron donor (Fig. 2).

\section{Genetic analysis}

DNA-DNA hybridization demonstrated a close relationship among the isolates. ASO3-1 and AHT 8 were related on the species level (75\% similarity), while AHT 6 represented a different genomic species (55\% similarity to ASO3-1). The $16 \mathrm{~S}$ rRNA gene-based phylogenetic analysis demonstrated that the isolates belonged to the family Desulfohalobiaceae in the Deltaproteobacteria, and represented a novel lineage with 93.4\% sequence similarity to the nearest culturable relative (Fig. 3). Sequence similarity was $99.4 \%$ between AHT 8 and ASO3-1, and 98.5\% between AHT 6 and ASO3-1.

\section{Fatty acid composition of the membrane polar lipids}

The signature fatty acid dominating the cellular lipids of the novel isolates was isoC $\mathrm{C}_{15: 0}$. It is also present at a relatively high amount in a halophilic member of the Desulfohalobiaceae, Desulfohalobium retbaense, but not in its low salt-tolerant alkaliphilic relative Desulfonatronovibrio (Supplementary Table S1). ASO3-1 also differed from the other species, including AHT 6, by the presence of a high amount of the fatty acid isoC $17: 1$. In general, a dominance of the unsaturated fatty acids in the cellular lipids was evident for all four (halo)alkaliphilic representatives of the family Desulfohalobiaceae.

\section{Compatible solutes}

Analysis of intracellular compatible solutes in strains ASO3-1 grown with lactate and sulfite at $3 \mathrm{M}$ total $\mathrm{Na}^{+}$ indicated the presence of glycine betaine at a high specific concentration (16\% from the total cell mass). This is a first indication of the presence of this osmolyte in the Deltaproteobacteria.
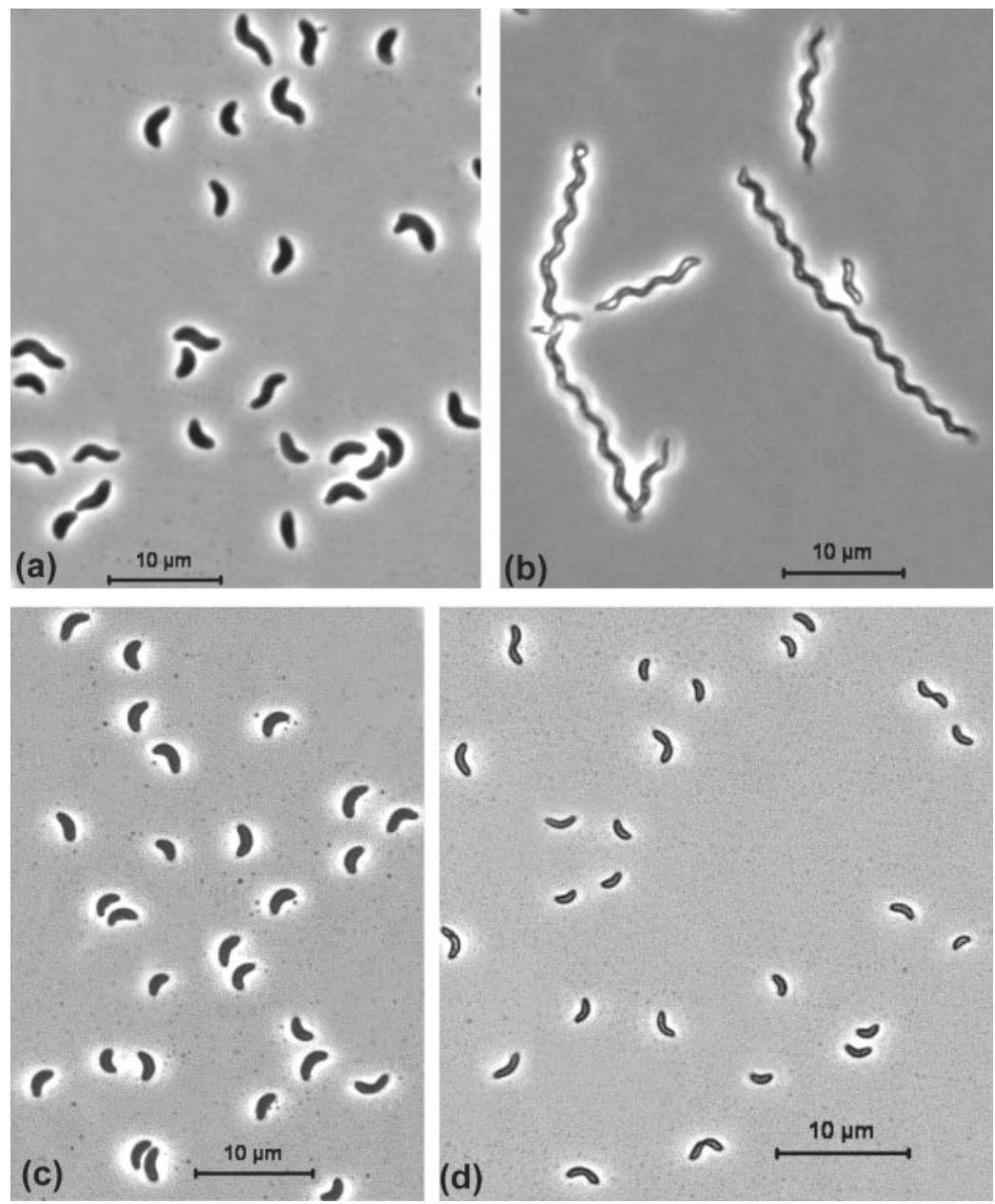

Fig. 2. Cell morphology of strains ASO3-1 (a, b), AHT 8 (c) and AHT 6 (d) grown at $2 \mathrm{M}$ total $\mathrm{Na}^{+}$and $\mathrm{pH}$ 10. (a, c) Cultures grown with sulfite alone; (b) culture grown with lactate as electron donor and a carbon source and sulfite as electron acceptor. Panels $(a-d)$ are phasecontrast photomicrographs. 


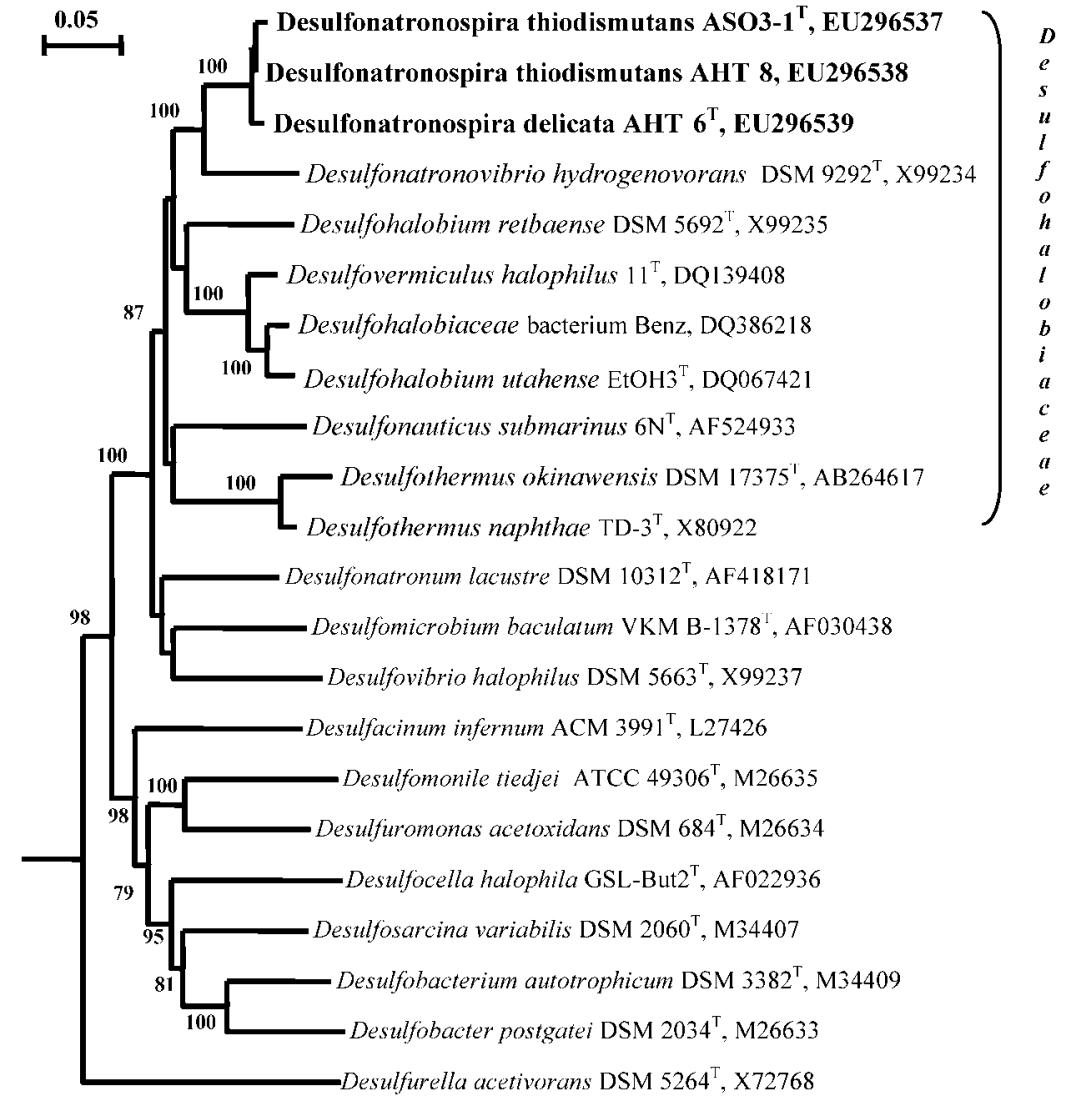

Fig. 3. Phylogenetic position based on $16 \mathrm{~S}$ rRNA gene sequence analysis of high salttolerant alkaliphilic SRB from hypersaline soda lakes in the Deltaproteobacteria. Tree topography and evolutionary distances are given by the neighbour-joining method with Jukes and Cantor distances. Numbers at the nodes indicate the percentage of bootstrap values for the clade in 1000 replications. Only values above $70 \%$ are shown.

\section{Growth characteristics and metabolic properties}

The most interesting property of the isolates was their ability to grow by dismutation of sulfite and thiosulfate (inorganic fermentation) on purely mineral medium. The strains tolerated 12-15 mM sulfite and formed 0.20 0.22 mol sulfide per mol sulfite consumed, which closely corresponded to the theoretical value of $25 \%$ derived from the stoichiometry of the reaction $\left(4 \mathrm{SO}_{3}^{2-} \rightarrow \mathrm{HS}^{-}+3 \mathrm{SO}_{4}^{2-}\right)$. Dismutation of thiosulfate yielded approximately $0.92 \mathrm{~mol}$ sulfide per mol thiosulfate consumed, also in good agreement with the theoretical stoichiometry $\left(\mathrm{S}_{2} \mathrm{O}_{3}^{2-} \rightarrow\right.$ $\mathrm{HS}^{-}+\mathrm{SO}_{4}^{2-}$ ). All isolates were able to grow as true $\mathrm{SRB}$, using several electron donors, including hydrogen, formate, lactate and ethanol (Table 1). The addition of external electron donors abolished disproportionation of sulfite or thiosulfate and sulfur, and only sulfide was formed. The strains tolerated high concentrations of sulfite. The switch of the cultures from sulfite or thiosulfate to sulfate was very slow. The growth dynamics of strain ASO3-1 under different conditions are shown in Fig. 4. Its specific growth rates at $2 \mathrm{M} \mathrm{Na}^{+}$and $\mathrm{pH} 10$ with sulfite or thiosulfate alone were 0.010 and $0.006 \mathrm{~h}^{-1}$ (doubling times of 67 and $112 \mathrm{~h}$ ), respectively. The addition of lactate increased the growth rate 1.5- to twofold. The specific biomass yield during disproportionation was $1.3 \mathrm{mg}$ protein (per mmol $\mathrm{SO}_{3}^{2-}$ ) and $0.8 \mathrm{mg}$ protein (per mmol $\mathrm{S}_{2} \mathrm{O}_{3}^{2-}$ ). The influence of acetate on the growth of the isolates was of special interest, since AHT 6 was isolated as a presumed 'acetate-utilizing' SRB. However, with this strain we obtained the same result as during the first discovery of thiosulfate-disproportionating SRB by Bak \& Pfennig (1987): the bacterium was able to grow without acetate, which was utilized as a carbon source only during chemolithoheterotrophic growth. This was also the case for the other strains, isolated without acetate. For example, in AHT 6, the biomass yield per mol thiosulfate increased 1.5- to twofold when 1-5 mM acetate was added, while no further increase up to $20 \mathrm{mM}$ acetate was obtained. With strain ASO3-1 grown with sulfite, the effect of acetate addition was much less evident: only a $30 \%$ increase in biomass yield and rate of sulfite consumption was obtained. The experiments with $\left[{ }^{14} \mathrm{C}\right]$ acetate confirmed that acetate served as a carbon source only in the case of AHT 6.

Short-term experiments with washed cells of ASO3-1 (Table 2) demonstrated that the cells grown with thiosulfate as electron acceptor actively reduced thiosulfate, sulfite and much less actively sulfate, while the cells grown with sulfite could only reduce sulfite and sulfate. This indicated that thiosulfate reductase activity was inducible, and that the reduction of thiosulfate most probably goes through sulfite. The cells grown on thiosulfate exhibited extremely high sulfidogenic activity with elemental sulfur. However, growth with sulfur as acceptor was not observed. 
Table 1. Properties of sulfidogenic strains from hypersaline soda lakes

Abbreviations: BtOH, butanol; EtOH, ethanol; ND, not determined.

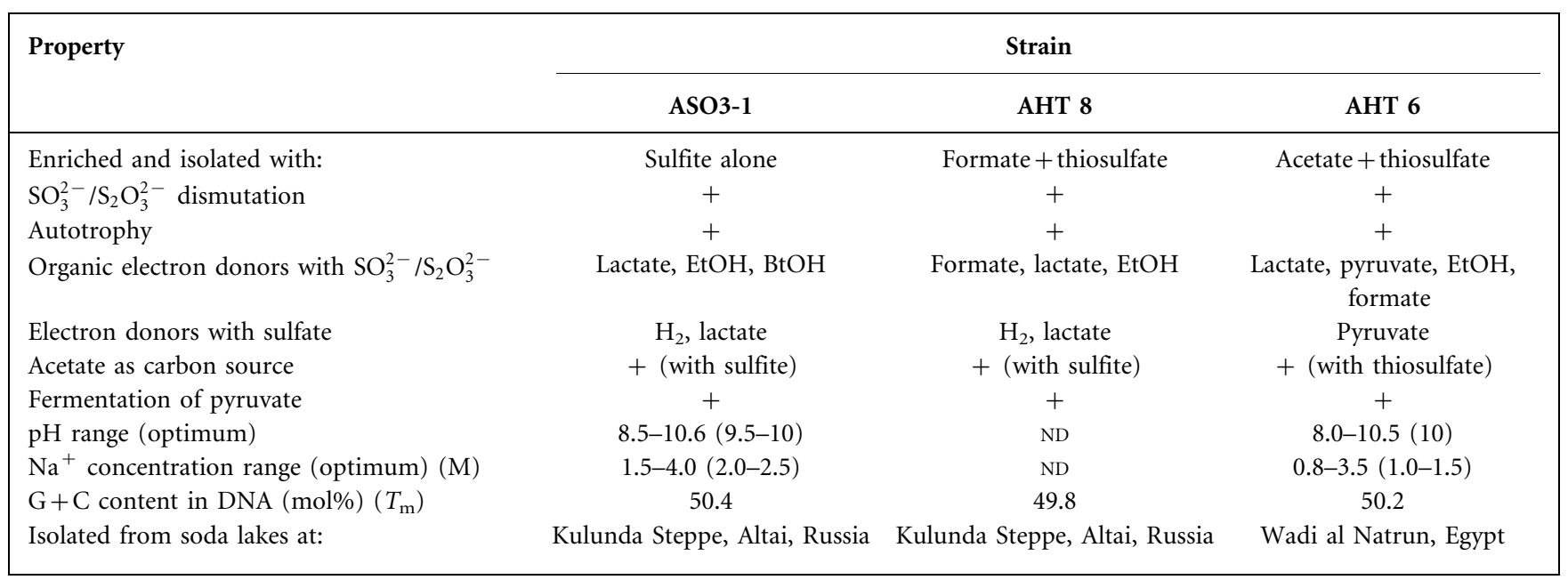

Clearly, the enzymic system involved in thiosulfate disproportionation is able to actively reduce elemental sulfur. This property is known, for example, for the dissimilatory thiosulfate-reducing complex Phs (Hinsley \& Berks, 2002). On the other hand, the toxicity of produced polysulfide (a spontaneous reaction product of sulfide and sulfur) might be a reason for the failure of growth with sulfur as acceptor in all species of alkaliphilic SRB so far described.

To elucidate the pathway of inorganic carbon fixation, key enzyme activities characteristic of the reverse TCA cycle, the reductive acetyl-CoA pathway and hydrogenase were tested in CFEs obtained from strain ASO3-1 grown with sulfite or $\mathrm{H}_{2}$ plus thiosulfate. The activity of the key enzymes of the reverse TCA cycle, malate dehydrogenase, alpha-ketoglutarate oxidoreductase and ATP citrate lyase, could not be detected. Key activities of the reductive acetylCoA pathway, CO and formate oxidation, were detected in CFE of sulfite-grown [carbon monoxide dehydrogenase
(CODH), $0.08 \mathrm{U} \mathrm{mg}{ }^{-1}$; formate dehydrogenase (FDH),

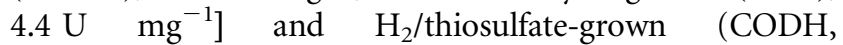
$0.27 \mathrm{U} \mathrm{mg}^{-1}$; FDH, $3.9 \mathrm{U} \mathrm{mg}^{-1}$ ) cells. Hydrogenase activity was readily detectable in $\mathrm{H}_{2}$ plus thiosulfate-grown cells (5.4 $\left.\mathrm{U} \mathrm{mg}^{-1}\right)$, but was insignificant in sulfite-grown cells $\left(0.01 \mathrm{U} \mathrm{mg}^{-1}\right)$.

\section{Influence of pH and salt on growth and sulfidogenic activity}

The $\mathrm{pH}$ profile for growth and sulfidogenic activity measured for strains ASO3-1 and AHT 6 at $2 \mathrm{M}$ total $\mathrm{Na}^{+}$was typical for obligate alkaliphiles, with a $\mathrm{pH}$ range from $8.0-8.5$ to 10.5 and an optimum at $\mathrm{pH} 9.5-10$ (Fig. 5b). The sodium concentration range for growth and sulfidogenic activity tested in sodium carbonate-based medium at $\mathrm{pH} 10$ was different for the two strains. While strain ASO3-1 can be qualified as an extreme natronophile unable to grow properly at salt contents below $1.5 \mathrm{M} \mathrm{Na}^{+}$ and growing at up to $4 \mathrm{M} \mathrm{Na}^{+}$, AHT 6 was less salt-
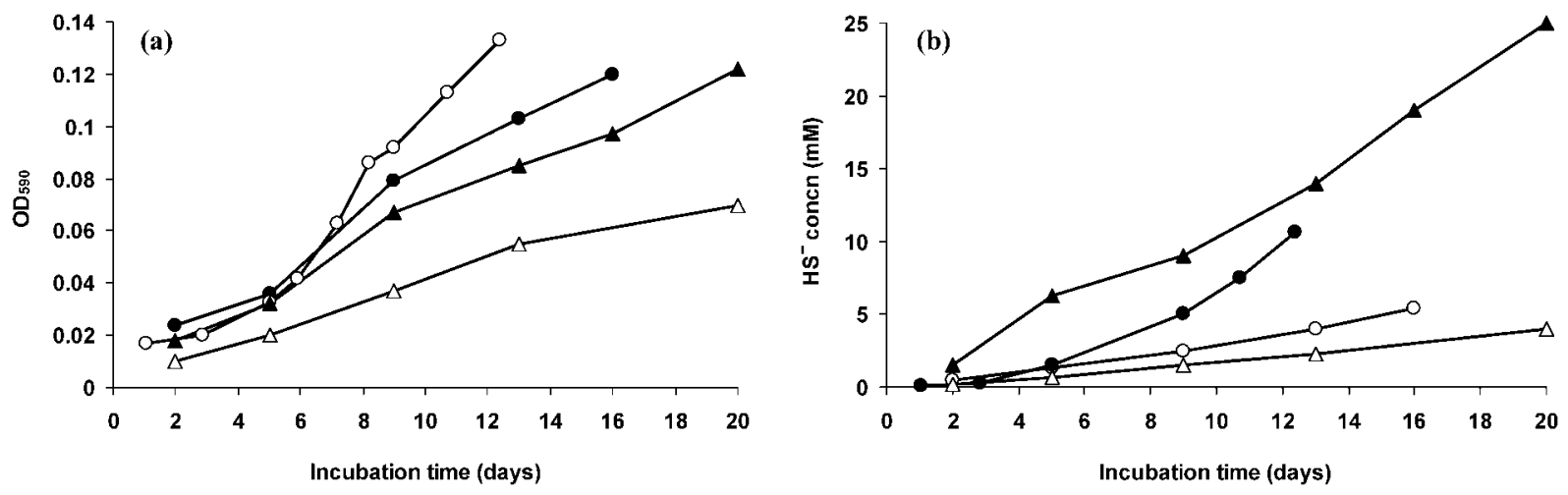

Fig. 4. Anaerobic growth (a) and sulfide production (b) of strain ASO3-1 at $2 \mathrm{M}$ total $\mathrm{Na}^{+}, \mathrm{pH} 10$, with sulfite alone ( $\bigcirc$ ), thiosulfate alone $(\triangle)$, lactate + sulfite $(\bullet)$ and $\mathrm{H}_{2}+$ thiosulfate $(\boldsymbol{\Delta})$. 
Table 2. Sulfidogenic activity of washed cells of strain ASO3-1 grown with lactate and either sulfite or thiosulfate as electron acceptor

The cells $\left(0.2 \mathrm{mg}\right.$ protein $\left.\mathrm{ml}^{-1}\right)$ were incubated in sodium carbonate buffer at $2 \mathrm{M} \mathrm{Na}^{+}, \mathrm{pH} 10$, with $10 \mathrm{mM}$ lactate as the electron donor.

\begin{tabular}{|c|c|c|}
\hline \multirow[t]{2}{*}{ Electron acceptor } & \multicolumn{2}{|c|}{ Sulfidogenic activity $\left[\mathrm{nmol} \mathrm{HS}{ }^{-}(\mathrm{mg} \text { protein })^{-1} \min ^{-1}\right.$ ] } \\
\hline & Cells grown with sulfite & Cells grown with thiosulfate \\
\hline Sulfate & 18 & 14 \\
\hline Sulfite & 89 & 60 \\
\hline Thiosulfate & 11 & 72 \\
\hline Sulfur & 23 & 250 \\
\hline
\end{tabular}

dependent, starting to grow actively at $0.8 \mathrm{M}$ and tolerating up to $3.5 \mathrm{M}$ total $\mathrm{Na}^{+}$(Fig. 5a). Such a high salt tolerance as that observed in these isolates has not, as far as we know, been reported before for the known alkaliphilic SRB.

\section{DISCUSSION}

The high sulfide concentration and the results of activity measurements in the sediments of hypersaline soda lakes indicated the presence of a sulfidogenic population active at extremely high salt $/ \mathrm{pH}$. The fact that thiosulfate was a much better electron acceptor for the indigenous sulfidogens, and that sulfite and thiosulfate were better than sulfate for isolation of pure cultures, can be explained by the fact that sulfate needs to be activated prior to reduction, while such an energy-requiring activation is not necessary for sulfite and thiosulfate reduction. This is an important saving of energy under extreme conditions (Oren, 1999). The question of where sulfite and thiosulfate come from is not new. It has been treated before for marine sediments (Jørgensen, 1990). However, in soda lakes, thiosulfate could be a particularly important intermediate, since it is the main product of spontaneous polysulfide oxidation. Polysulfide $\left(\mathrm{S}_{\mathrm{x}}^{2-}\right)$ is a sulfur species that is stable under anoxic alkaline conditions; it is formed by the spontaneous reaction of elemental sulfur with sulfide. Once sulfide is formed by reduction of sulfate, the active cycling of thiosulfate might commence after partial oxidation of sulfide to sulfur in the micro-oxic zone. Active polysulfide/ thiosulfate formation was recently documented in a laboratory-scale sulfide-oxidizing bioreactor operating under extremely natronophilic conditions (Van den Bosch et al., 2007).

In our previous work on the molecular diversity of SRB in soda lake sediments using the $d s r A B$ gene as a molecular marker (Foti et al., 2007), a large group of organisms clustered with the low salt-tolerant Desulfonatronovibrio hydrogenovorans isolated from the hypersaline soda lake Magadi. However, from these data it was not possible to predict whether those bacteria are different with respect to (a)

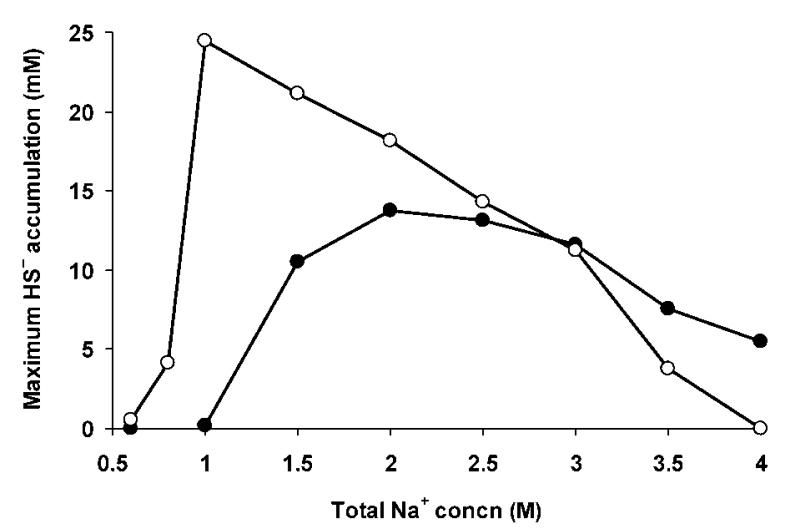

(b)

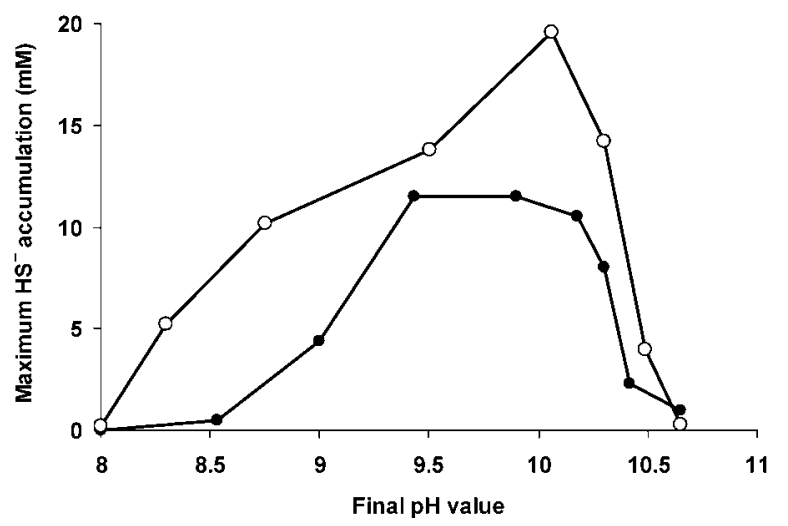

Fig. 5. Influence of $\mathrm{pH}$ at $2 \mathrm{M} \mathrm{Na}^{+}(\mathrm{a})$ and sodium carbonate at $\mathrm{pH} 10$ (b) on sulfidogenesis during anaerobic growth of strain ASO3-1 with lactate + sulfite $(\bullet)$ and strain AHT 6 with pyruvate + thiosulfate $(\bigcirc)$. The following buffer systems were used: for the $\mathrm{pH}$ range 7-8, 0.1 $\mathrm{M} \mathrm{HEPES} / 2 \mathrm{M} \mathrm{NaCl}$; for the $\mathrm{pH}$ range 8.2-8.5, $0.5 \mathrm{M} \mathrm{NaHCO}_{3} / 1.5 \mathrm{M} \mathrm{NaCl}$; for the $\mathrm{pH}$ range 9-11, $1.8 \mathrm{M} \mathrm{Na}^{+}\left(\mathrm{NaHCO}_{3} / \mathrm{Na}_{2} \mathrm{CO}_{3}\right) / 0.2 \mathrm{M} \mathrm{NaCl}$. The $\mathrm{pH}$ is plotted as 'Final $\mathrm{pH}$ value', since it was not constant within all of the range shown. 
salt tolerance. Analysis of the $d s r A B$ gene of a pure culture of the extremely natronophilic strain ASO3-1 demonstrated that it is indeed a member of the cluster within the family Desulfohalobiaceae found in the soda lake sediments (Foti et al., 2007). This family accommodates two groups of neutrophilic SRB able to cope with the highest $\mathrm{NaCl}$ concentrations among the known SRB, the genera Desulfohalobium (Ollivier et al., 1991) and Desulfovermiculus (Belyakova et al., 2006). The extremely natronophilic isolates from the hypersaline soda lakes form a new phylogenetic lineage within this extremophilic SRB family.

The ability to grow by disproportionation of sulfur compounds has been described before for only a few SRB species (Bak \& Pfennig, 1987; Janssen et al., 1996; Finster et al., 1998), including the low salt-tolerant moderate alkaliphile Desulfonatronum thiodismutans (Pikuta et al., 2003) and some other species that can disproportionate sulfur compounds without growth, such as Desulfonatronovibrio hydrogenovorans (Sydow et al., 2002). So far, the only known species able to grow by dismutation of sulfite and thiosulfate chemoautotrophically is the obligately disproportionating Desulfocapsa sulfoexigens. Our growth experiments (the potential to grow in the absence of organic carbon source) and enzymic tests (i.e. the presence of the Wood cycle enzymes) indicated that the extremely natronophilic isolates from the hypersaline soda lakes are capable of an autotrophic mode of growth. However, this must be substantiated by evidence of inorganic carbon incorporation into the cells. The stoichiometry of sulfide production during sulfite and thiosulfate dismutation was slightly lower than the theoretical values, which could be explained by the consumption of reducing equivalents needed for inorganic carbon reduction for cell mass synthesis. Despite the fact that the novel isolates grew under doubly extreme conditions $(\mathrm{pH}$, salt), the specific growth yield during dismutative growth was close to the values obtained for non-extremophilic SRB species (Bak \& Pfennig, 1987), indicating an efficient energy conservation mechanism. The latter is indeed needed for these bacteria, since the formation of high amounts of the organic osmolyte glycine betaine requires substantial energy (Oren, 1999). Two facts might be taken into consideration in this respect: (i) the virtual lack of toxic $\mathrm{H}_{2} \mathrm{~S}$ species at $\mathrm{pH} 10$ (which is important for the dismutating SRB); and (ii) the more negative $\Delta G$ values that result from the low proton concentration (which is important if the catabolic reaction takes place in the periplasm facing external alkaline conditions). On the other hand, extreme conditions can definitely be held responsible for the very low specific growth rates observed, which were five to 10 times lower than in the non-extremophilic SRB species growing by dismutation.

In conclusion, extremely natronophilic SRB found in hypersaline soda lakes are proposed to form a novel genus within the family Desulfohalobiaceae, class Deltaproteobacteria, for which the name Desolfonatronospira is suggested. The closely related strains ASO3-1 and AHT 8 form a novel species Desulfonatronospira thiodismutans, while strain AHT 6 is proposed as another species Desulfonatronospira delicata.

\section{Description of Desulfonatronospira gen. nov.}

Desulfonatronospira (de.sul.fo.na.tro.no.spi'ra L. prep. de, from; N.L. pref. sulfo-, prefix used for N.L. masc. n. sulfas atis, sulfate; N.Gr. n. natron, arbitrarily derived from the Arabic n. natrun or natron, soda; L. fem. n. spira, a spire; N.L. fem. n. Desulfonatronospira, desulfurizing soda-loving spirillum).

Gram-negative bacterium with vibrio-shaped cells of variable size. Obligately anaerobic with respiratory or fermentative metabolism. Uses sulfur oxyanions as electron acceptor, and short-chain fatty acids and $\mathrm{H}_{2}$ as electron donors. Can grow by dismutation of sulfite and thiosulfate. Obligately alkaliphilic and extremely salt-tolerant. Belongs to the family Desulfohalobiaceae, order Desulfovibrionales within the Deltaproteobacteriae. The type species is Desulfonatronospira dismutans. Habitat: hypersaline soda lakes.

\section{Description of Desulfonatronospira thiodismutans sp. nov.}

Desulfonatronospira thiodismutans (thi.o.dis.mu'tans Gr. n. thios, sulfur; L. particle dis, in two, apart; L. part. adj. mutans, changing, altering; N.L. part. adj. thiodismutans, dismutating sulfur).

Cells are Gram-negative, vibrio-shaped, with size variable from single vibrio to long spirillum, depending on growth conditions, $0.6-0.8 \times 2-30 \mu \mathrm{m}$, motile by a single polar flagellum. Strictly anaerobic with respiratory or fermentative metabolism. Respiration with sulfate/sulfite/thiosulfate as acceptors is possible during autotrophic growth with either formate or hydrogen as electron donor, or with simple organic compounds such as lactate, ethanol and butanol. Acetate alone can be used as a carbon source. Fermentative growth occurs either by the inorganic chemolithoautotrophic mode through dismutation of sulfite or thiosulfate to sulfide and sulfate or by the organic mode through fermentation of pyruvate. Obligately alkaliphilic, with a $\mathrm{pH}$ range for growth between 8.3 and 10.5 and an optimum at $\mathrm{pH} 10$, and extremely natrono (soda)philic with a total $\mathrm{Na}^{+}$ range for growth from 1.5 to $4.0 \mathrm{M}$ (optimum at 2.0$2.5 \mathrm{M})$. Mesophilic, with a maximum temperature for growth of $43^{\circ} \mathrm{C}$. The dominant fatty acids in the membrane lipids include iso $\mathrm{C}_{15: 0}$, iso $\mathrm{C}_{17: 1}$ and $\mathrm{C}_{16: 0}$. Cells accumulate high concentrations of glycine betaine as a compatible solute. The G+C content of the genomic DNA is 49.8$50.4 \mathrm{~mol} \%\left(T_{\mathrm{m}}\right)$. The species includes two closely related strains. The type strain ASO3- $1^{\mathrm{T}}\left(\mathrm{DSM} 19093^{\mathrm{T}}=\mathrm{UNIQEM}\right.$ $\mathrm{U}_{234^{\mathrm{T}}}$ ) and strain AHT 8 were isolated from the Kulunda Steppe soda lakes (Altai, Russia). The GenBank 16S rRNA sequence accession numbers of these strains are EU296537 and EU296538, respectively. 


\section{Description of Desulfonatronospira delicata sp. nov.}

Desulfonatronospira delicata (del.i.ca'ta. L. fem. adj. delicata, delicate).

Cells are Gram-negative, vibrio-shaped, $0.4-0.6 \times 1.2-$ $4.0 \mu \mathrm{m}$, motile by a single polar flagellum. Strictly anaerobic with respiratory metabolism or fermentative metabolism. Respiration with sulfate/sulfite/thiosulfate as acceptors is possible during autotrophic growth with either formate or hydrogen as electron donor, or with simple organic compounds such as lactate, pyruvate and ethanol. Acetate can be used as a carbon source. Fermentative growth occurs either by the inorganic chemolithoautotrophic mode through dismutation of sulfite/thiosulfate to sulfide and sulfate or by the organic mode through fermentation of pyruvate. Obligately alkaliphilic, with a $\mathrm{pH}$ range for growth between 8.0 and 10.6 and an optimum at $\mathrm{pH} 10$, and extremely natronotolerant with a total $\mathrm{Na}^{+}$range for growth from 0.8 to $3.5 \mathrm{M}$ (optimum at $1.0 \mathrm{M})$. Mesophilic, with a maximum temperature for growth of $45^{\circ} \mathrm{C}$. The dominant fatty acids in the membrane lipids include iso $\mathrm{C}_{15: 0}, \quad 10 \mathrm{MeC}_{16: 01}$ and isoC $_{17: 0}$. The $\mathrm{G}+\mathrm{C}$ content of the genomic DNA is $50.2 \mathrm{~mol} \% \quad\left(T_{\mathrm{m}}\right)$. The type strain AHT $6^{\mathrm{T}}$ $\left(\right.$ DSM $\left.19491^{\mathrm{T}}=\mathrm{UNIQEM} \mathrm{U} 275^{\mathrm{T}}\right)$ was isolated from the Wadi al Natrun haloalkaline lakes in Egypt. The GenBank $16 \mathrm{~S}$ rDNA sequence accession is EU296539.

\section{ACKNOWLEDGEMENTS}

This work was supported by the Netherlands Organization for Scientific Research-Russian Foundation for Basic Research (NWORFBR) (grant 047.011.2004.010), the RFBR (grant 06-04-00153), by the Program on Molecular and Cell Biology of the Russian Academy of Sciences (RAS), and by a grant of the STW (The Netherlands), with financial support from Shell Global Solutions (Amsterdam, The Netherlands) and Paques BV (Balk, The Netherlands). We are grateful to G. A. Osipov for the analysis of cellular fatty acid composition and to A. M. Lysenko for the total DNA analysis.

\section{REFERENCES}

Bak, F. \& Pfennig, N. (1987). Chemolithotrophic growth of Desulfovibrio sulfodismutans sp. nov. by disproportionation of inorganic sulfur compounds. Arch Microbiol 147, 184-189.

Belyakova, E. V., Rozanova, E. P., Borzenkov, I. A., Tourova, T. P., Pusheva, M. A., Lysenko, A. M. \& Kolganova, T. V. (2006). The new facultatively chemolithoautotrophic, moderately halophilic, sulfatereducing bacterium Desulfovermiculus halophilus gen. nov., sp. nov., isolated from an oil field. Microbiology(English translation of Mikrobiologiia) 75, 161-171.

De Ley, J., Caffon, H. \& Reinaerts, A. (1970). The quantitative measurement of DNA hybridization from renaturation rates. Eur $J$ Biochem 12, 133-140.

Finster, K., Liesack, W. \& Thamdrup, B. (1998). Elemental sulfur and thiosulfate disproportionation by Desulfocapsa sulfoexigens sp. nov., a new anaerobic bacterium isolated from marine surface sediment. Appl Environ Microbiol 64, 119-125.
Foti, M., Sorokin, D. Yu., Lomans, B., Mussmann, M., Zacharova, E. E., Pimenov, N. V., Kuenen, J. G. \& Muyzer, G. (2007). Diversity, activity and abundance of sulfate-reducing bacteria in saline and hypersaline soda lakes. Appl Environ Microbiol 73, 2093-2100.

Foti, M. J., Sorokin, D. Yu., Zacharova, E. E., Pimenov, N. V., Kuenen, J. G. \& Muyzer, G. (2008). Bacterial diversity and activity along a salinity gradient in soda lakes of the Kulunda Steppe (Altai, Russia). Extremophiles 12, 133-145.

Galinski, E. A. \& Herzog, R. M. (1990). The role of trehalose as a substitute for nitrogen-containing compatible solutes. Arch Microbiol 153, 607-613.

Hinsley, A. P. \& Berks, B. C. (2002). Specificity of respiratory pathways involved in the reduction of sulfur compounds by Salmonella enterica. Microbiology 148, 3631-3638.

Janssen, P. H., Schuhmann, A., Bak, F. \& Liesack, W. (1996). Disproportionation of inorganic sulfur compounds by the sulfatereducing bacterium Desulfocapsa thiozymogenes gen. nov., sp. nov. Arch Microbiol 166, 184-192.

Jørgensen, B. B. (1990). A thiosulfate shunt in the sulfur cycle of marine sediments. Science 249, 152-154.

Kulp, T. R., Hoeft, S. E., Miller, L. G., Saltikov, C., Murphy, J. N., Han, S., Lanoil, B. \& Oremland, R. S. (2006). Dissimilatory arsenate and sulfate reduction in sediments of two hypersaline, arsenic-rich soda lakes: Mono and Searles Lakes, California. Appl Environ Microbiol 72, 6514-6526.

Marmur, J. (1961). A procedure for isolation of DNA from microorganisms. J Mol Biol 3, 208-214.

Marmur, J. \& Doty, P. (1962). Determination of the base composition of deoxyribonucleic acid from microorganisms. J Mol Biol 5, 109-118.

Ollivier, B., Hatchikian, C. E., Prensier, G., Guezennec, J. \& Garcia, J. L. (1991). Desulfohalobium retbaense gen. nov., sp. nov., a halophilic sulfate reducing bacterium from sediments of a hypersaline lake in Senegal. Int J Syst Bacteriol 41, 74-81.

Oren, A. (1999). Bioenergetic aspects of halophilism. Microbiol Mol Biol Rev 63, 334-348.

Pfennig, N. \& Lippert, K. D. (1966). Über das Vitamin $B_{12}$-Bedürfnis phototropher Schwefelbacterien. Arch Microbiol 55, 245-256 (in German)..

Pikuta, E. V., Zhilina, T. N., Zavarzin, G. A., Kostrikina, N. A., Osipov, G. A. \& Rainey, F. A. (1998). Desulfonatronum lacustre gen. nov., sp. nov.: a new alkaliphilic sulfate-reducing bacterium utilizing ethanol. Microbiology (English translation of Mikrobiologiia) 67, 105-113.

Pikuta, E. V., Hoover, R. B., Bej, A. K., Marsic, D., Whitman, W. B., Cleland, D. \& Krader, P. (2003). Desulfonatronum thiodismutans sp. nov., a novel alkaliphilic, sulfate-reducing bacterium capable of lithoautotrophic growth. Int J Syst Evol Microbiol 53, 1327-1332.

Ryu, J.-H., Dahlgren, R. A., Gao, S. \& Tanji, K. K. (2004). Characterization of redox processes in shallow groundwater of Owens Dry Lake, California. Environ Sci Technol 38, 5950-5957.

Schauder, R., Widdel, F. \& Fuchs, G. (1987). Carbon assimilation pathways in sulfate-reducing bacteria II. Enzymes of a reductive citric acid cycle in the autotrophic Desulfobacter hydrogenophilus. Arch Microbiol 148, 218-225.

Scholten, J. C. M., Joye, S. B., Hollibaugh, J. T. \& Murrell, J. C. (2005). Molecular analysis of the sulfate reducing and archaeal community in a meromictic soda lake (Mono Lake, California) by targeting $16 \mathrm{~S}$ rRNA, mcrA, apsA, and dsrAB genes. Microb Ecol 50, 29-39.

Sorokin, D. Yu. \& Kuenen, J. G. (2005). Haloalkaliphilic sulfuroxidizing bacteria in soda lakes. FEMS Microbiol Rev 29, 685-702.

Sorokin, D. Y., Gorlenko, V. M., Namsaraev, Z. B., Lysenko, A. M., Eshinimaev, B. T., Khmelenina, V. N., Trotsenko, Y. A. \& Kuenen, J. G. 
(2004). Prokaryotic communities of the north-eastern Mongolian soda lakes. Hydrobiologia 522, 235-248.

Sorokin, D. Y., Banciu, H., Robertson, L. A. \& Kuenen, J. G. (2006). Haloalkaliphilic sulfur-oxidizing bacteria. In The Prokaryotes, vol. 2, Ecophysiology and Biochemistry, pp. 969-984. Edited by M. Dworkin, S. Falkow, E. Rosenberg, K. H. Schleifer \& E. Stackebrandt. New York: Springer.

Sydow, U., Wohland, P., Wolke, I. \& Cypionka, H. (2002). Bioenergetics of the alkaliphilic sulfate-reducing bacterium Desulfonatronovibrio hydrogenovorans. Microbiology 148, 853-860.

Trüper, H. G. \& Schlegel, H. G. (1964). Sulfur metabolism in Thiorhodaceae. 1. Quantitative measurements on growing cells of Chromatium okenii. Antonie Van Leeuwenhoek 30, 225-238.

Van de Peer, Y. \& De Wachter, R. (1994). TREECON for Windows: a software package for the construction and drawing of evolutionary trees for the Microsoft Windows environment. Comput Appl Biosci 10, 569-570.
Van den Bosch, P. L. F., van Beusekom, O. C., Buisman, C. J. N. \& Janssen, A. J. H. (2007). Sulfide oxidation at halo-alkaline conditions in a fed-batch bioreactor. Biotechnol Bioeng 97, 1053-1063.

Zeikus, J. G., Fuchs, G., Kenealy, W. \& Thauer, R. K. (1977). Oxidoreductases involved in cell carbon synthesis of Methanobacterium thermoautotrophicum. J Bacteriol 132, 604-613.

Zhilina, T. N., Zavarzin, G. A., Rainey, F. A., Pikuta, E. N., Osipov, G. A. \& Kostrikina, N. A. (1997). Desulfonatronovibrio hydrogenovorans gen. nov., sp. nov., an alkaliphilic, sulfate-reducing bacterium. Int J Syst Bacteriol 47, 144-149.

Zhilina, T. N., Zavarzina, D. G., Kuever, J., Lysenko, A. M. \& Zavarzin, G. A. (2005). Desulfonatronum cooperativum sp. nov., a novel hydrogenotrophic, alkaliphilic, sulfate-reducing bacterium, from a syntrophic culture growing on acetate. Int J Syst Evol Microbiol 55, 1001-1006.

Edited by: H.-P. Klenk 